\title{
Citrus Mealybug (Hemiptera: Pseudococcidae) Movement and Population Dynamics in an Arbor-Trained Vineyard
}

Author(s): M. Cid, S. Pereira, C. Cabaleiro, and A. Segura

Source: Journal of Economic Entomology, 103(3):619-630. 2010.

Published By: Entomological Society of America

DOI: $10.1603 / \mathrm{EC} 09234$

URL: http://www.bioone.org/doi/full/10.1603/EC09234

BioOne (www.bioone.org) is an electronic aggregator of bioscience research content, and the online home to over 160 journals and books published by not-for-profit societies, associations, museums, institutions, and presses.

Your use of this PDF, the BioOne Web site, and all posted and associated content indicates your acceptance of BioOne's Terms of Use, available at www.bioone.org/page/terms of use.

Usage of BioOne content is strictly limited to personal, educational, and non-commercial use. Commercial inquiries or rights and permissions requests should be directed to the individual publisher as copyright holder. 


\title{
Citrus Mealybug (Hemiptera: Pseudococcidae) Movement and Population Dynamics in an Arbor-Trained Vineyard
}

\author{
M. CID,${ }^{1,2,3}$ S. PEREIRA, ${ }^{1,4}$ C. CABALEIRO, ${ }^{5}$ AND A. SEGURA ${ }^{1}$
}

\begin{abstract}
J. Econ. Entomol. 103(3): 619-630 (2010); DOI: 10.1603/EC09234
ABSTRACT The citrus mealybug, Planococcus citri (Risso) (Hemiptera: Pseudococcidae), is the main grapevine pest in vineyards in some countries, such as Spain and Brazil. In Galician vineyards (northwestern Spain), mealybug population levels are low because the accumulated degree-days are lower than in other grapevine-growing areas. The main problem caused by mealybugs is the transmission of viruses, even at low infestation levels. The active period of citrus mealybug in the study vineyard lasted from July until December, with an important movement peak at the end of July and August and a lower peak in November. The mealybug mainly moved upward along arbor-trained plants, and there were no important downward movements at the end of the season as has been described for other grapevine mealybugs. The mealybugs were normally restricted to the woody organs and were only present on leaves, branches, and green canes (always close to woody parts) in plants with high infestations. The movement of mealybugs between plants does not seem to take place by contact between green organs. Passive aerial transport and movement of pruning remains may play an important role in mealybug movement and thus in spread of the virus. The number of mealybugs carrying Grapevine leafroll-associated virus $3(\mathrm{GLRaV}-3)$ was found to represent $\approx 75 \%$ of mealybugs caught in a GLRaV-3 infected vineyard.
\end{abstract}

KEY WORDS insect, citrus mealybug, Planococcus citri, grapevine, Grapevine leafroll-associated virus 3

Mealybugs are important pests in grapevine culture (Bentley et al. 2006a,b; Varela et al. 2006). They have two direct effects: reduction of plant vigor at high population levels, and devaluation of fruit due to the presence of mealybugs on grape bunches. Further indirect effects on photosynthesis and on fruit marketability also occur as a result of the sooty mold that grows on the honeydew produced by the mealybug, and as a result of the transmission of important grapevine viruses (GVA, GVB, Grapevine leafrollassociated virus [GLRaV]-1, GLRaV-3, GLRaV-5, and GLRaV-9), even at low infestation levels (Golino et al. 2002).

Planococcus ficus (Signoret) and grape mealybug, Pseudococcus maritimus (Ehrhorn), are the two most important mealybug species that are considered as vineyard pests and that cause serious problems in all wine-growing areas. Other species such as citrus mealybug, Planococcus citri (Risso); obscure mealybug, Pseudococcus viburni Signoret; and Pseudo-

\footnotetext{
${ }^{1}$ Dpto de Fisioloxía Vexetal, Fac. de Bioloxía, Univ. de Santiago de Compostela, 15782 Santiago de Compostela, Spain.

${ }^{2}$ Current address: Instituto de Ciencias Agrarias, Centro de Ciencias Medioambientales, Consejo Superior de Investigaciones Científicas, CSIC, c/Serrano 115 dpdo, 28006 Madrid, Spain.

${ }^{3}$ Corresponding author, e-mail: ghuises@ccma.csic.es.

${ }^{4}$ Centro de Investigacións Agrarias de Mabegondo, INGACAL, Xunta de Galicia, Apdo 10, 15080-A Coruña, Spain.

${ }^{5}$ Dpto de Producción Vexetal. Escola Politécnica Superior, Univ. de Santiago de Compostela. 27002 Lugo, Spain.
}

coccus longispinus (Targioni-Tozzetti) are less important pests of grapevine because they affect smaller areas and produce fewer direct economic losses.

The citrus mealybug is a highly polyphagous mealybug and is considered a pest of many crops, especially of citrus orchards. P. citri is not usually found in most wine-growing areas but it is almost the only mealybug found in vineyards in Galicia (northwestern Iberian Peninsula) (Cabaleiro and Segura 1997a) and Brazil (Morandi et al. 2008). The ability of the citrus mealybug to transmit GLRaV-3 and GVA has been demonstrated in laboratory assays (Rosciglione and Castellano 1985; Cabaleiro and Segura 1997a,b; Golino et al. 2002). The field transmission of GLRaV-3 by mealybugs has been demonstrated in an arbor-trained vineyard in Galicia naturally infested by $P$. citri $(\mathrm{Ca}-$ baleiro and Segura 1997a). This vineyard displayed a low level of citrus mealybug infestation, and mealybugs did not cause crop loss.

GLRaV-3 is the most widespread grapevine virus. It has been reported in all major grape-growing areas around the world. The main effect of the virus is a decrease in must quality - specifically a decrease in sugar content and an increase in acidity - and a decrease in grapevine yield by, on average, 15-20\% (Martelli and Boudon-Padieu 2006).

Arbor training of vines is common practice in southeastern Galicia. This particular type of training is used 


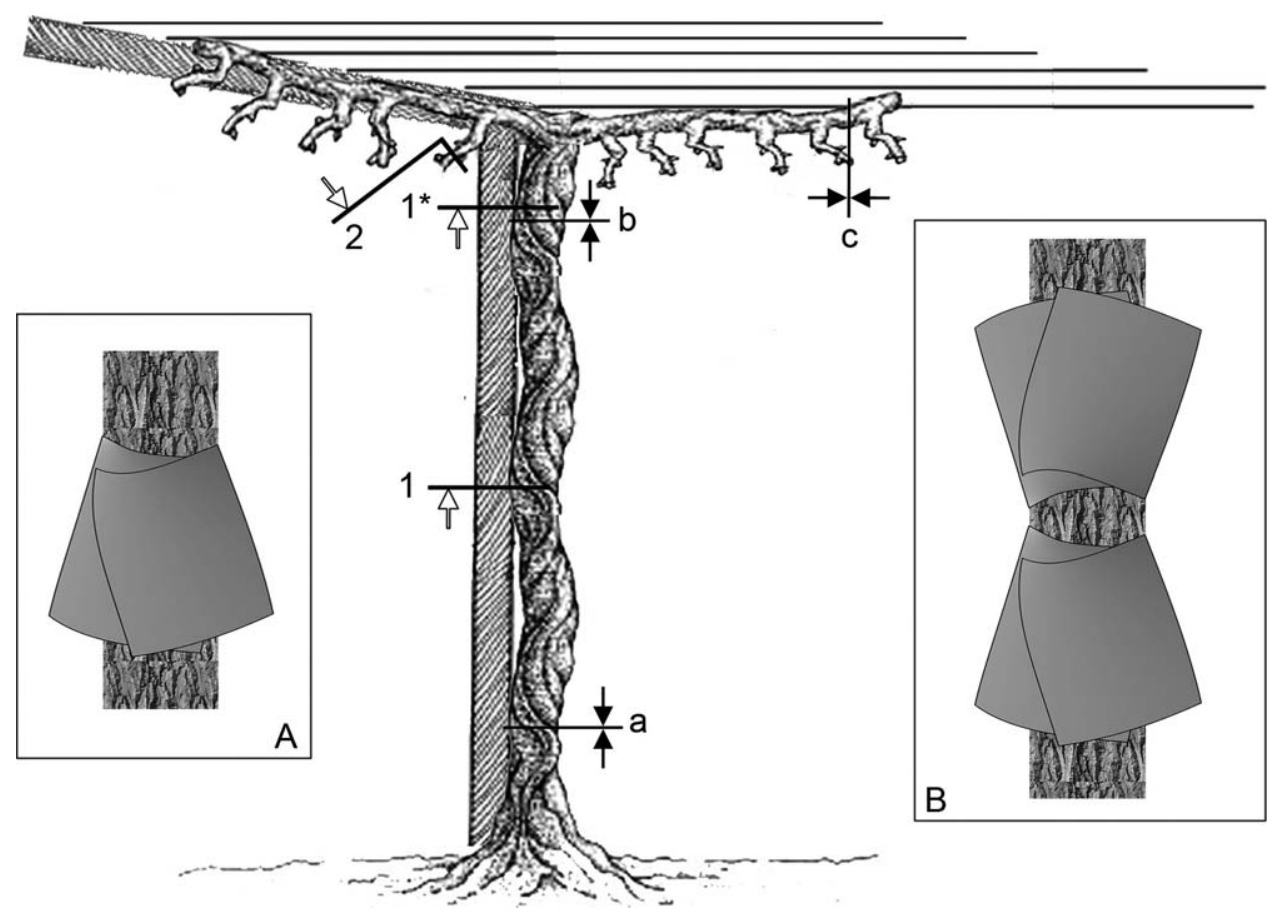

Fig. 1. Diagram of an arbor-trained grapevine with the traps locations. The white arrows show the places where the traps to study the temporal movement of mealybugs were placed $\left(1\right.$ and $1^{*}$ indicate the trunk traps of the two groups of plants created, and 2 indicates the cane trap). The facing black arrows show the places were the double traps to study the movement of mealybugs through the plant were placed ( $\mathrm{a}, \mathrm{b}$, and c indicate the traps of the lower, middle, and upper levels, respectively). The box A shows a diagram of a simple sticky trap used to study the temporal movement of mealybugs. The box B shows a diagram of a double sticky trap used to study the movement of mealybugs through the plant.

to prevent fungal attack (as the plant canopy is separated from the soil) and is used in low-lying areas with high relative humidity. The branches of the current year's growth in plants trained in this way grow to make a continuous canopy, with close contact between plants during most of the season.

The presence of citrus mealybug in vineyards was not considered an important research topic until recently; few studies were carried out (Ruiz Castro 1965) and more attention was given to the citrus pest (Bodenheimer 1951, Berlinger and Gol'berg 1978, Krishnamoorthy and Singh 1987). The discovery of the ability of mealybugs to transmit the grapevine virus increased the general interest in P. citri and other mealybugs that are vineyard pests. Several studies focused on the biology (Morandi et al. 2008), behavior (Geiger and Daane 2001, Lo et al. 2006, Grasswitz and James 2008), and detection and control of the mealybugs (Walton et al. 2004; Walton and Pringle 2004a,b, Bentley et al. 2006a,b), and on its role in field virus transmission (Cabaleiro and Segura 1997a, Golino et al. 2002, Cabaleiro et al. 2008).

The importance of the insects' movements in the virus transmission process remains unknown. The aim of the current study was therefore to describe the pattern of movements of $P$. citri on arbor-trained grapevine plants and to analyze the role of mealybug movement in the field transmission of GLRaV-3.

\section{Materials and Methods}

Vineyard. The experiments were performed in a vineyard in Beluso (Galicia, northwestern Spain) (516838.94 UTMX 29-T, 4685556.97 UTMY 29-T), which comprises several plots. The vineyard has been described in previous papers, and the field transmission of the GLRaV-3 by mealybugs has been monitored at the site for $>15$ yr (Cabaleiro and Segura 1997a). The plot used in the current study, plot $F$, was planted 20 yr ago with 'Tinta Femia' (the local name for the traditional red 'Caíno Tinto'). The plants were arbor-trained (Fig. 1) with a north-south orientation. The mealybug infestation in the vineyard was first observed in this plot and was generally conspicuous. The sampled plants were located on the north third of the plot, which represent $\approx 0.1 \mathrm{ha}$. All plants in this plot are infected with GLRaV-3.

Climate Parameters. The climatic data (temperature, moisture, and rainfall) during the sampling period were obtained from the nearest climate recording station (Lourizan: 527749 UTMX 29-T, 4695489 UTMY 29-T) placed at $15 \mathrm{~km}$ from the study location. The station is part of the Sistema de Información Ambiental de Galicia climate monitoring station network, and the data were downloaded from www.meteogalicia.es. Historical data from the climate station were obtained from Carballeira et al. (1983). 
Temporal Study of Mealybugs Movement. The temporal study of movement was performed with the aid of adhesive traps placed on several parts of the plants. The mealybugs were trapped to determine the timing of peak occurrence and to relate this to the possibility of virus transmission.

The sampling was carried out in three seasons, beginning in May 2003 and ending in February 2006. Sampling in 2003-2004 was carried out on two plants selected on the basis of the presence of overwintering females under the trunk bark. The sampling in 20042005 began on 20 plants where either overwintering females or remains of woolly laying were present, although sampling of two of these plants was discontinued at the end of the summer because no mealybugs were detected. In 2005-2006, the same 18 plants as in the previous year were sampled.

Two adhesive traps were placed on each plant (Fig. $1)$ : one trap on the trunk and the other trap on a branch $20 \mathrm{~cm}$ away from the trunk. In the 2004-2006 sampling, two different groups of plants were established to obtain additional data about the distribution and movement of the mealybugs. The trunk trap in the first group was placed at $0.8 \mathrm{~m}$ from the soil, as in 2003-2004 sampling, and in the second group it was placed at $1.7 \mathrm{~m}$ from the soil, close to the trellis. Each trap consisted of packaging tape wound around the trunk, or branch, to make a funnel with the wide part facing downward (Fig. 1A). The bark was removed from around the trunk before the trap was put in place, to ensure good adherence and to avoid movement of the mealybugs under the tape. The mealybugs were trapped on the inward side of the tape when they moved along the plant. New traps were placed in the same position on subsequent sampling dates. The tapes were removed and replaced weekly in July, August, and September. The period that elapsed between placement and removal of the trap during the other months varied between $1 \mathrm{wk}$ and $1 \mathrm{mo}$, depending on the level of capture and the environmental conditions.

The insects trapped on the tapes were counted in the laboratory in a stereomicroscope. Two classes of insects were established according to the development stage of the mealybugs: nymphs, including the first and second nymphal stages, and adults, including the third nymphal stages and female adults. The presence of other insects that may affect the mealybug populations, including ants, was recorded. The number of captures per trap was corrected according to the number of days that elapsed between placement and removal of the trap. Thus, the rate of capture was expressed as the number of insects trapped per day.

The capture data from the trunk traps in the two plant groups were square root transformed. The transformed values were compared for each sampling date by means of a nonparametric Mann-Whitney analysis (StatView 4.02, Abacus Concepts, Berkeley, CA).

Movement of Mealybugs Through the Plants. The movement of the mealybugs through the plants was analyzed during the 2005-2006 season. The sampling periodicity was the same as described above. Adhesive traps were placed on five plants, as described above, but at three height levels: one trap at $30-40 \mathrm{~cm}$ from the soil; a second trap at $170 \mathrm{~cm}$ from the soil; and a third trap on top, on a branch $50 \mathrm{~cm}$ from the previous trap (Fig. 1). Two adhesive traps were placed at each level: the lower trap at each level was arranged with the wider part facing downwards and the upper trap with the wider part facing upwards (Fig. 1B). Thus, mealybugs that moved up through the plant fell into the lower trap, and those that came down were caught in the upper trap. Each sampling date the tapes were replaced an the removed traps were transported to the laboratory and the number of captured insects counted as described above. The movement at each level was valuated as the average per plant of diary net movement and that was the number of mealybugs trapped in the lower trap minus number of mealybugs caught in the upper trap divided by the time, expressed in days that elapsed between placement and removal of the trap.

Location of Mealybugs on Plants. The location of mealybugs was monitored throughout the season by visual sampling on five plants during the 2005-2006 season. The sampling periodicity was the same as described above. Three sampling areas were established: the trunk, between the soil and the first fork; the old (several-years-old) lignified branches; and the canopy, which comprises the 1-yr-old branches, leaves, and bunches. Two experimenters sampled each plant part simultaneously for $2 \mathrm{~min}$, so that each plant was therefore sampled for $12 \mathrm{~min}$. The infestation level was measured separately for adults and nymphs according to a four-class scale: 1) absence of individuals, 2) low infestation level (1-3 individuals), 3) intermediate level (4-10 individuals), and 4) high level (>10 individuals). A numerical value was assigned to each abundance class for the calculations: 0 , absence of mealybugs; 1.5 , low level; 7.5 , intermediate level; and 15 , high level of infestation. The average values obtained for each sampling area were compared date by date by means of a Kruskal-Wallis test (StatView 4.02, Abacus Concepts).

Abundance of Potentially Viruliferous Mealybugs. Sampling was carried out to calculate the number of potentially viruliferous mealybugs during the 20042005 season. The periodicity of samplings was similar to that described above. Three mealybugs were collected from each plant on each sampling day, from the same five plants. Adult mealybugs were collected preferentially, but in the absence of adults, nymphal stages (as large as possible) were collected. The virus was detected on whole individuals by immunocapture reverse transcription-polymerase chain reaction (ICRT-PCR) (Cid et al. 2007) performed with commercial antibodies against GLRaV-3 (Bioreba, Reinach, Switzerland) and with the primers designed by Minafra and Hadidi (1994). The ratio of positive to total mealybugs analyzed in the course of the season was compared by means of chi-squared goodness-of-fit test (StatView 4.02, Abacus Concepts). 

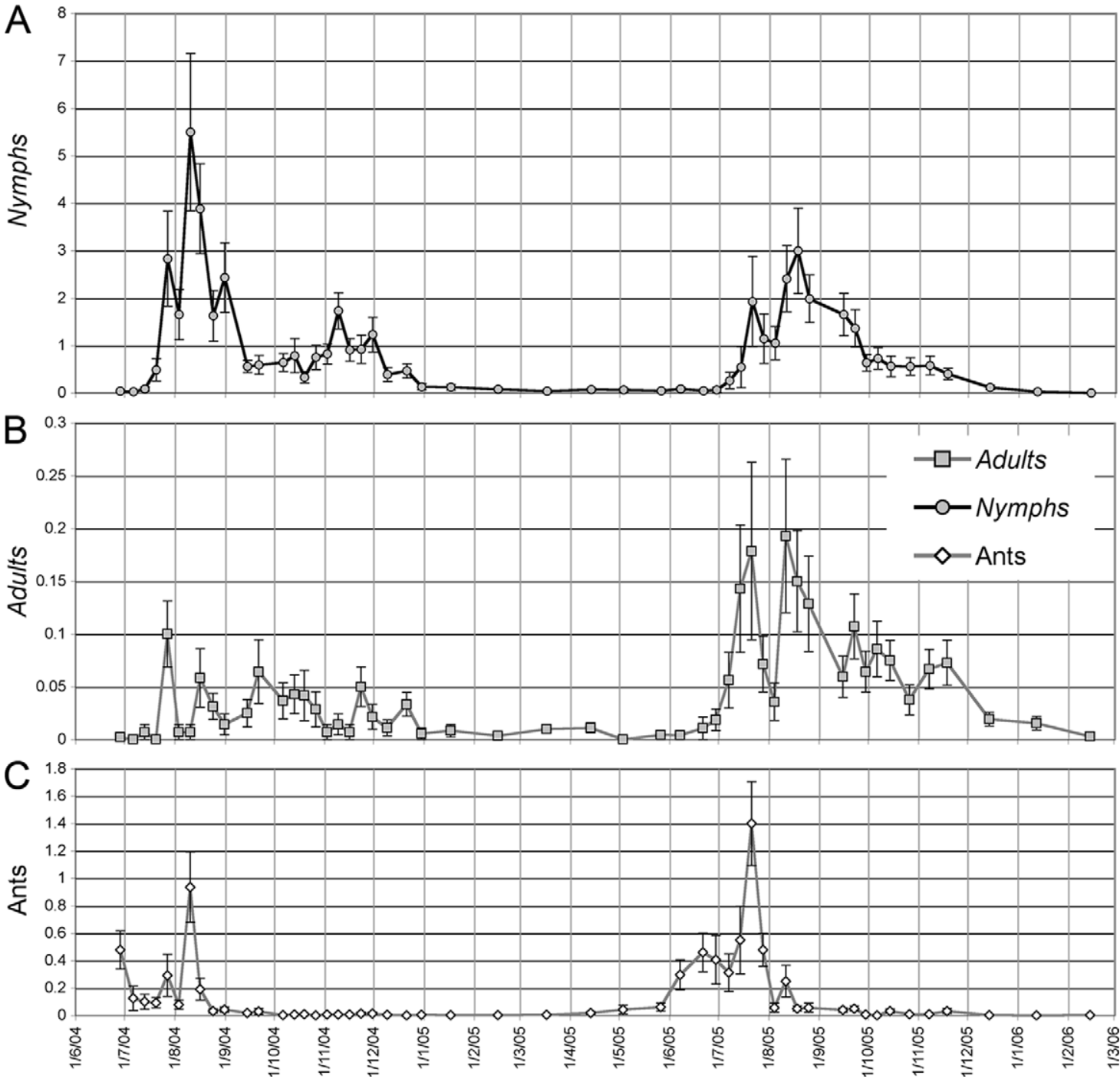

Fig. 2. Captures of mealybugs and ants per day and plant in 2004-2006. (A) Numbers of mealybug nymphs captured (first and second nymphal stage). (B) Numbers of mealybug adults captured (third nymphal stage and adults). (C) Number of ants captured throughout 2004-2006 period. The ordinate axis represents the insects captured in the single sticky traps per day and plant during the sampling to determine the timing of peak movements.

\section{Results}

Temporal Study of Mealybug Movements. Mainly first and second nymphal stages were captured and only a few adults and third nymphal stage were found. The average number of nymphs, adults, and ants captured per day and plant for 2004 and 2005 are shown in Fig. 2. This indicates the clear prevalence of nymphal stages and a slight similarity between the capture profile of adults and nymphs. The period of $P$. citri movement lasted from mid-July until the end of the year (Fig. 3). However, a few mealybugs were captured before and after that period. Peak movements occurred during the two last weeks of July and in August. After the first peak movements the level of capture fell and remained low until November when a new peak movement took place, although much less than in summer. The number of mealybugs captured varied greatly among plants and among years. On some plants, fewer mealybugs were captured in 2004 than in 2005, but on other plants more were captured in 2004. Because of the great differences between plants in terms of the infestation level and in the shape of the capture curve, significant differences between the two groups of plants on the basis of the height of the trunk trap were only detected in one of 52 sampling dates (Mann-Whitney $U$ test ( $P$ value for 14 December 2005 was 0.0413).

Movement of Mealybugs Through Plants. The levels of infestation differed greatly in the five plants sampled. A high level of infestation was observed in 

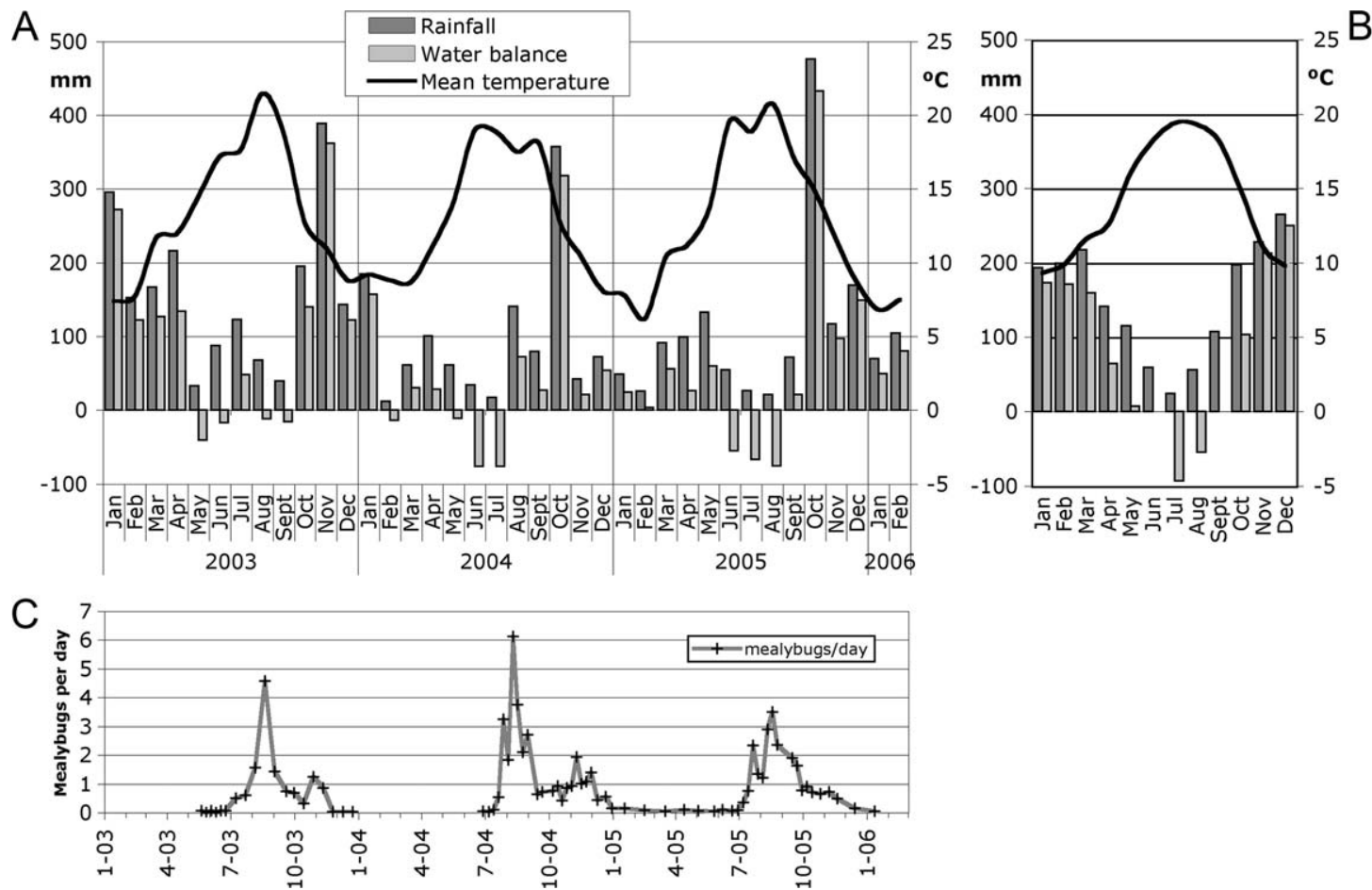

Fig. 3. Mealybug captures and meteorological parameters throughout the study period. (A) Changes in the main climatic parameters: mean temperature (Celsius), accumulated rainfall along the month (millimeters), and the monthly water balance (rainfall minus evapotranspiration; millimeters) as a drought estimate registered in the nearby Lourizán meteorological station (data obtained from www.meteogalicia.es). (B) Historical values of these three variables at the same meteorological station (Carballeira et al. 1983); C shows the evolution in mealybugs captures during the three year period of sampling. The captures are expressed as the average numbers of captures per day and plant.

two plants (1,666 and 1,082 mealybugs were caught during the sampling in these plants) and a low level of infestation in the other three plants $(94,244$, and 286 mealybugs were caught in these plants). The average value per plant of the diary net movement of nymphs (N1 and N2 nymphs) for each level shows a predominant upward movement (Fig. 4A). There was a notable downward movement on the lower zone of the plants in the second half of July and on the middle zone in the second half of September. The other descending movements were occasional and usually involved small numbers of mealybugs. The most significant were those detected in mid October on the middle zone and in mid November on the lower and middle zones. The movement pattern of adults (N3 nymphs and adults) was quite different from the nymphal movement pattern (Fig. 4B). The upward movement was predominant on the middle and upper zones, but on the lower zone the downward movement was the main type of movement. It is important to note the number of adults caught was really lower than that of nymphs. The movement of adults recorded in the upper and middle traps was mainly upward with only a few occasional downward movements: in early August on the middle zone and in mid-August and mid-October on the upper zone.

Location of Mealybugs on Plants. The visual sampling indicated that the mealybugs preferred the trunk and woody branches (Fig. 5). Of the five sampled plants, mealybugs were consistently present on two of the canopies (two fifths) and sporadically on one canopy. In these cases, the mealybugs were always located next to the woody part, and settled on the three or four basal internodes and their respective leaves.

Regarding the woody part of the plant, more mealybugs were observed on the trunk than on the woody branches in four fifths of the plants. The plant with the most mealybugs on the branches was the only plant in which mealybugs were present on bunches, and even then only on bunches that were in contact with the wood.

The graphical representation shows the clear prevalence of the woody parts as refuge for the mealybugs and its scarce presence on the canopy (Fig. 5). The location on the different zones differed between nymphs and adults. The presence of adults on the canopy was low and it showed a maximum in September, whereas the nymphs were more irregularly present on the canopy, with frequent peaks from June to August and a maximum a month sooner than the adults. The trunk played a major role as a refuge for both adults, from mid-June to mid-December, and nymphs, from late June to early November. The woody branches also were used as refuge throughout the season but were particularly important between 

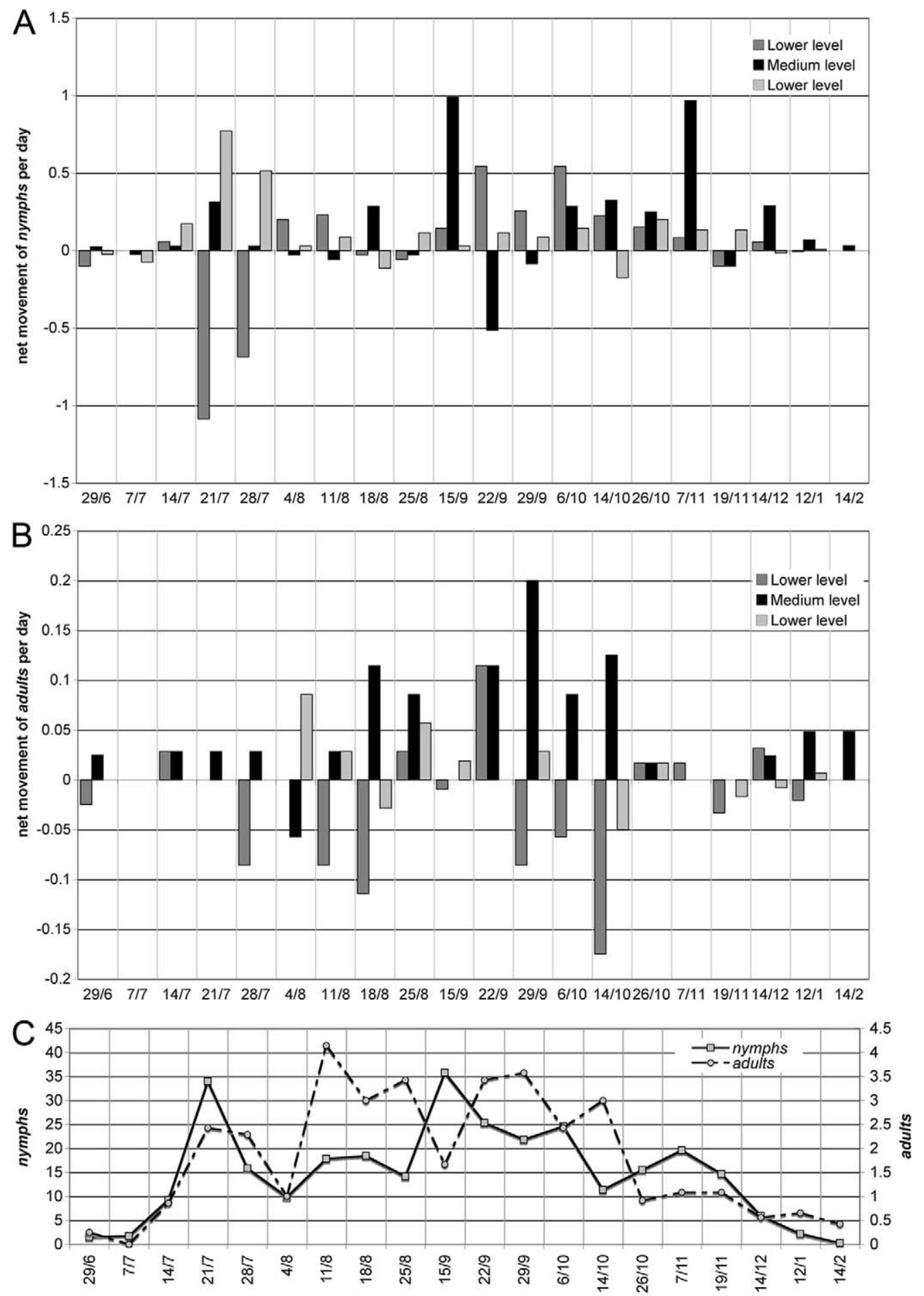

Fig. 4. Net movement of mealybugs at three different heights of the grapevines in 2005-2006. (A and B) Net movement averaged per plant for the double sticky traps placed at the bottom of the trunk (lower level) in dark gray, at the top of the trunk (medium level) in black, and on the woody branches (upper level) in light gray (see Fig. 1). The value shown for each sampling date is the average per plant of subtract from the numbers of captures of the facing-down trap, which catch mealybugs going up, the captures of the facing-up trap, which catch mealybugs going down. The value is positive when the net movement is upward and negative when it is downward. (A) Nymphal data (N1 and N2) captures. (B) Adult (N3 and adults) captures. (C) Data for total captures per day that is the result of add the captures of all the traps of the five sampled plants and divide it by the time, expressed as days, that the traps were on the plant. 

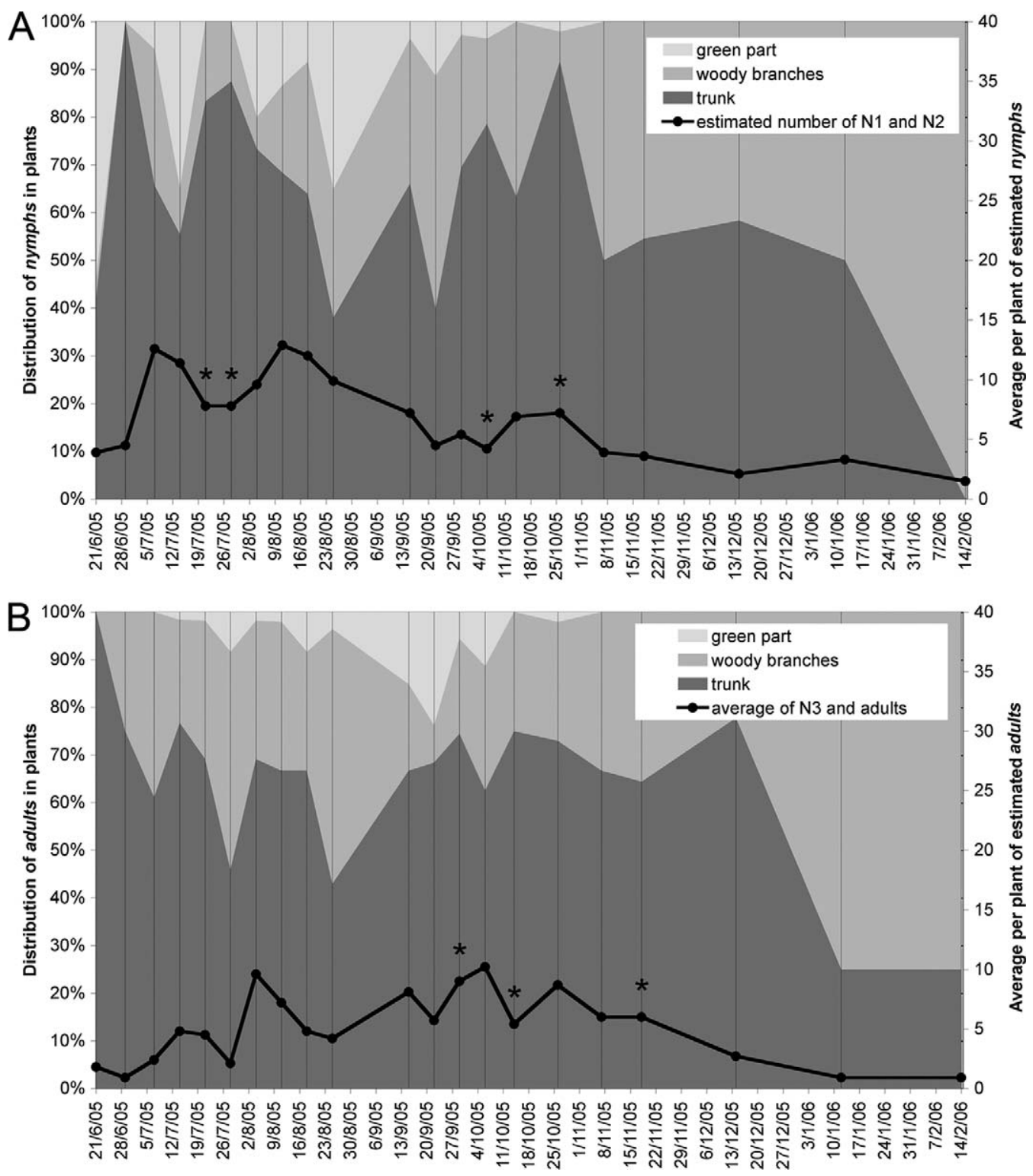

Fig. 5. Distribution of mealybugs on the plants. The graphs show the distribution of mealybugs on the trunk, the woody branches, and the green parts (leaves, branches, and bunches) throughout 2005-2006 season. The data were obtained by a visual sampling, and a value of abundance was assigned to each plant zone according with a four steps scale $(0$, absence of mealybugs, 1.5 between one and five mealybugs, 7.5 between six and 10 mealybugs, and 15 for $>10$ mealybugs). For each sampling date and plant, we calculated the distribution of mealybugs (nymphs [N1 and N2] or adults [N3 and adults]) as percentages, and the data shown are the average per plant of these percentages. The black lines represent the number of mealybugs (nymphs or adults) estimated per plant (sum of abundance values of all the zones and plants divided by the number of sampled plants). The sampling dates marked with an asterisk $(*)$ are those with significant differences (Kruskal-Wallis test: $\mathrm{df}=2, P<0.05)$ among the percentages of mealybugs placed on each zone.

mid-November and February due to the high level of infestation observed on the branches in only one in five plants.

The data were analyzed by means of Kruskal-Wallis test to compare the distribution of mealybugs on the plants. The large differences among plants allowed only to find statistical differences on three dates for adults distribution (Kruskal-Wallis: $\mathrm{df}=2, P<0.05$, on 29 September 2005, 14 October 2005, and 18 November 2005) and four dates for nymphs distribution (Kruskal-Wallis: $\mathrm{df}=2, P<0.05$, on 21 July 2005, 28 July 2005, 6 October 2005, and 26 October 2005).

Potentially Viruliferous Mealybugs. The GLRaV-3 was detected in $10-13$ of 15 mealybugs between midJuly and mid-October (Fig. 6); thereafter, the number of mealybugs decreased, and it was impossible to col- 


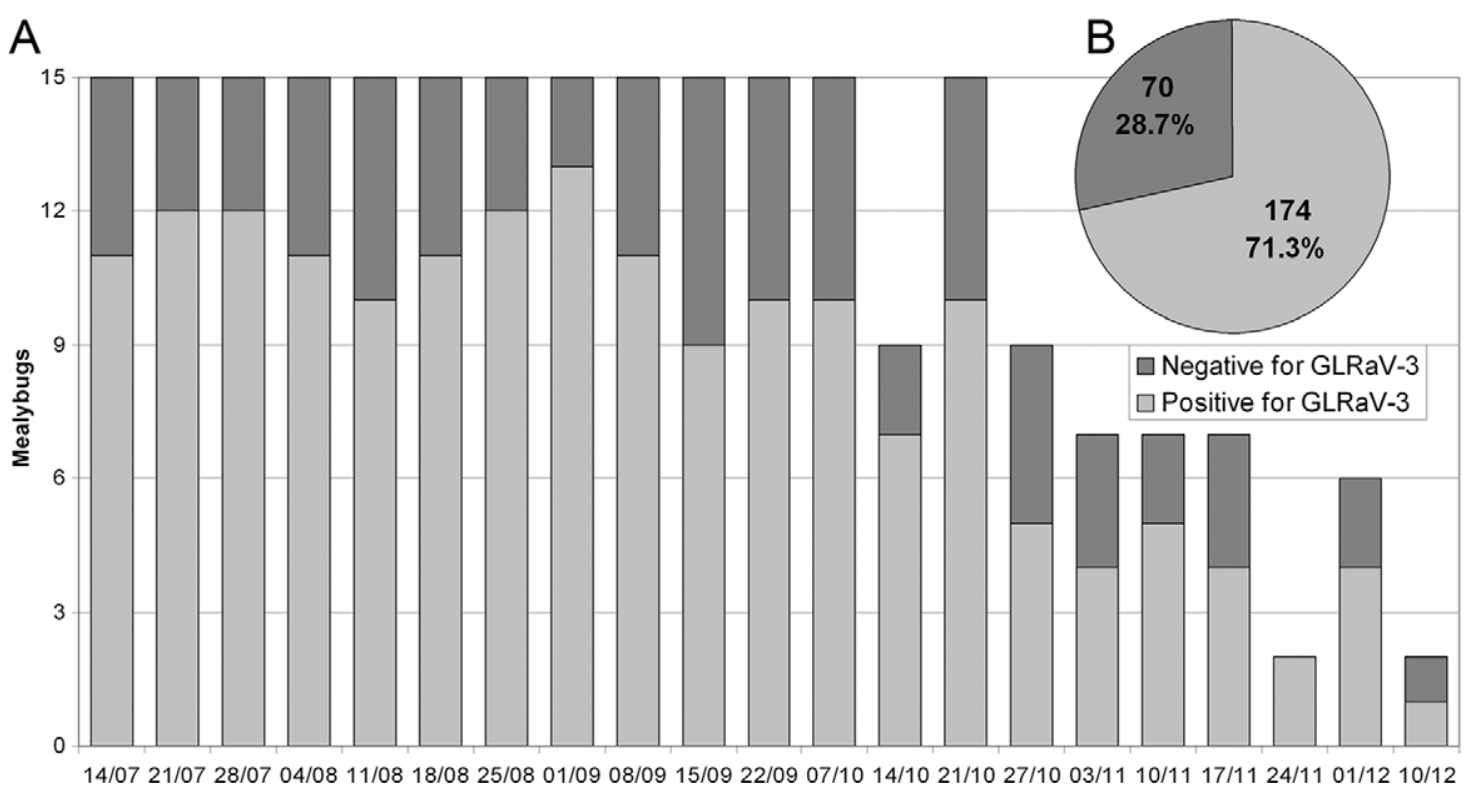

Fig. 6. Number of potentially infective mealybugs. (A) Differences in the number of mealybugs tested as positive and negative for the presence of GLRaV-3 throughout the year. Three mealybugs were collected from each of five plants infected with the virus. From mid-October, it became impossible to collect enough mealybugs, and very low numbers of mealybugs were analyzed. Whole mealybugs were analyzed by IC-RT-PCR. No significant differences were detected between the obtained values of viruliferous mealybugs and the expected values (71.3\% of viruliferous mealybugs) (chi-squared goodness to fit test: $\chi^{2}=9.042, \mathrm{df}=20, P=0,9824$ ). (B) Total number of positive and negative individuals (for the presence of the virus) throughout the year.

lect five individuals per plant. In all samples that consisted of 15 individuals, the percentage of GLRaV-3carrying mealybugs remained quite similar and varied between 67 and $80 \%$. Overall the percentage of GLRaV3-carrying mealybugs during the entire season was $72 \%(170 / 235)$. The chi-squared goodness to fit test showed no differences between the obtained values of viruliferous mealybugs and the expected ones $(71.3 \%$ of viruliferous mealybugs $)\left(\chi^{2}=9.042, \mathrm{df}=20, P=\right.$ $0.9824)$.

Mealybug Biotic Relations. Capture of other animals on the traps provided information about their possible biotic relation with the mealybugs. The main interaction seemed to be with ants, which were consistently trapped throughout the season. The ant capture peaks were detected between June and midAugust (Fig. 2). The pattern of ant captures displayed one or two peaks simultaneous to the first peaks in mealybug captures, with an additional peak before the start of mealybug movements. From August onward, the capture of ants decreased and was then very low for the rest of the year. Shelters made by the ants to protect the mealybugs were detected during sampling, mainly on the lowest sector of the trunk.

Tyrophagus putrescentiae (Schrank) (Astigmata: Acaridae) was present in variable numbers throughout the entire study. Their abundance was not quantified. But during 2003 and 2004, the captures were limited to the autumn, coinciding with a decrease in mealybug numbers. However, in 2005, numbers of this mite were high throughout the season and coincided with abnormally low numbers of mealybug nymphs.
Predators and parasitoid wasps were not captured in the traps, although some parasitoid mummies were found glued to the traps. Most of these were already empty, and in the others the adult parasitoids did not hatch and were therefore impossible to identify. More mummies were captured in 2005 (27) than in 2004 (6).

\section{Discussion}

The season of activity of $P$. citri, during the annual cycle, lasts from early July until December. The citrus mealybug has no winter diapause (Bodenheimer 1951, Ruiz Castro 1965), as most the grapevine mealybugs, except Pseudococcus maritimus (Bentley et al. 2006b), and some activity is detected throughout the winter. Nevertheless, the low temperatures and the winter latency of the grapevine lead to almost total inactivity of the mealybugs. The overwintering population mainly comprises adult females, but it is not uncommon to find third and occasionally second nymphal stages, and they are located on the woody organs (the only ones which remain from one year to another) and mainly on the lower part of the trunk. These overwintering individuals lay their eggs in late spring or in early summer under the bark of the trunk and branches of several years. Hatching of eggs laid by the overwintering females gives rise to the first peak movement. These movements are reflected in the peak captures in late July and August. The slight synchronization of the mealybugs, generated by the winter effect, and the good environmental conditions give rise to a large number of hatchings in a short period of 
time, leading to peak movement. Once the summer peak movement occur the level of captures decreases and remains low until late autumn, when a new peak takes place. This second peak may be induced by the simultaneous hatching of eggs laid by the first no overwintering generation mealybugs and the enhanced quality of the sap phloem caused by nutrient retranslocation during leaf senescence (Nassar and Kliewer 1966, Kliewer 1967).

The very mobile nymphs move along the plant, mainly the trunk. Most do not reach the green organs and they remain under the bark. They prefer concealed places under the bark rather than the exposed parts of shoots and the leaves. The nymphs colonize the nearest portion of the green part, new shoots and basal leaves, only in plants with an abnormally high overwintering population or in plants with many overwintering mealybugs on the upper branches.

Most studies of mealybugs in vineyards refer to movements from the green part of the plants to the more concealed lower part of the trunk in late season (Ruiz Castro 1965; Berlinger 1977; Geiger and Daane 2001; Koplow Wies 2004; Bentley et al. 2006a,b; Varela et al. 2006). In the current study, sampling to determine the movement of mealybugs revealed the absence of downward peak movements of nymphs throughout the year except on the lower part in the second half of July, probably due to the spread of crawlers hatched from eggs laid above the lower trap. Nevertheless, adults moved upward at the two upper levels traps but the lower one captures showed a downward movement at this level. These results agree with the location of a winter shelter center between the lower and middle traps, whereas the adults tend to search winter shelters on the lower trunk. In this study, vineyard movement from the trunk to the canopy was not really necessary because of the very low numbers allowed to most of mealybugs to settle on the woody parts, under the bark, and return to the trunk was imperceptible or nonexistent. The number of overwintering females is therefore mainly determined by the number of mealybugs under the bark and their survival over the winter. Low temperatures, low grapevine activity, and high rainfall may be the main causes of mealybug deaths during the winter. When present in low numbers, overwintering citrus mealybugs are mainly located at the bottom of the trunk (Bodenheimer 1951, Ruiz Castro 1965, Berlinger 1977). These locations are protected against the rain and to a lesser extent against the low temperatures. The obscure mealybug and Phenacoccus manihoti Matile-Ferrero also display high mortality due to high rainfall (Le Rü and Iziquel 1990, Koplow Wies 2004).

The behavior of $P$. citri in the study vineyard is different from that described in a vineyard in Almería (southeastern Spain) (Ruiz Castro 1965). The level of infestation of the green part in the Almería vineyard was much higher than in the current study and rainfall favored explosions in mealybug populations. These differences may be mainly due to the climatic differences between locations: the climate in Almería is semiarid Mediterranean (average temperature [AT], $18.7^{\circ} \mathrm{C}$; average annual rainfall [AAR], $196 \mathrm{~mm}$; average relative moisture [ARM], 66\% [Instituto Nacional de Meteorología (España) 2001]), whereas the climate in the study area is oceanic $\left(\mathrm{AT}, 14.2^{\circ} \mathrm{C}\right.$; AAR, 1,800 mm; and ARM, 77.7\% [Carballeira et al. 1983, Meteogalicia 2009]). The annual temperatures range in Almería make it possible for the accumulated degree-days to be almost twice as high as in Galicia. This influences the number of generations produced by the mealybugs each year and therefore the final numbers. In Almería, activity begins earlier, in April, due to the higher temperatures. At this time, the mealybugs hatched from the eggs laid by overwintering females on the trunk colonize the sprouts and advance through the canopy as it grows, so that in August most of the mealybugs are located in the fruit. In October, the mealybugs return to concealed locations under the bark. In vineyards in southeastern Spain, relative humidity is an important variable in terms of the population dynamic of mealybugs: the rain and the subsequent increase in humidity cause population explosions (Ruiz Castro 1965, Lucas Espadas 2002), whereas the dry wind mainly causes the death of the youngest nymphs (Bodenheimer 1951, Ruiz Castro 1965). However, rain had a different effect in the study area, where the relative humidity is high throughout the season and thus does not limit development of the mealybugs.

The dynamics of other grapevine mealybugs, such as P. ficus, Ps. maritimus, and Ps. viburni, also differs. The behavior of these mealybugs varies depending on the species and the climatic features of the study location. The grape mealybug probably displays the most unusual behavior (Bentley et al. 2006b, Varela et al. 2006) due to synchronized generations; movement of the crawlers to the canopy, where they develop, and movement of adults to the woody part to lay the eggs. $P$. ficus infests the trunk during the spring and severely colonizes the canopy in summer when it lays eggs on leaves and grape clusters (Bentley et al. 2006b, Varela et al. 2006). In November, the population density declines and the nymphs migrate to the lower trunk. The obscure mealybug Ps. viburni behaves similarly to the vine mealybug (Koplow Wies 2004, Bentley et al. 2006b, Varela et al. 2006). Although it carries out the same type of movements, the level of infestation of the green part of the plants is lower than with the vine mealybug and the obscure mealybug does not lay eggs on leaves and grape clusters.

Geiger and Daane (2001) stated that the training system had an effect on the level of infestation. They detected larger populations of grape mealybugs, $P$ s. maritimus, and greater levels of damage in spurpruned vineyards than in the cane-pruned vineyards, in which mealybugs are more abundant on the green parts of the vines. Arbor-training may affect the movement and distribution of mealybugs through the plant. Plants trained in this way have a large amount of wood covered by a thick bark on the old plants. This large woody area allows the mealybug populations to increase in size without filling all the concealed locations under the bark. Thus, only when high temper- 
atures occur will the populations grow so large that the mealybugs will have to colonize the green parts, with deleterious effects on the crop yield. The bark of the arbor-trained plants is a large natural shelter for mealybugs. Thus, plants arbor trained are commonly and recurrently infested by mealybugs (Ruiz Castro 1965). The training system also affects the spread of the GLRaV-3 virus: the vertical-trained vineyard had a faster disease spread than the arbor-trained vineyard (Cabaleiro and Segura 2006).

The level of infestation reached in a season is mainly determined by: the level of infestation reached in the previous season, the duration and intensity of the warm season and the severity of the winter and its influence on survival over winter. In the $3 \mathrm{yr}$ of sampling, the level of infestation in the vineyard increased, probably because of the abnormally dry mild winters, especially in 2004-2005 (accumulated rainfall between September and February: historical average, 1,141 mm; 2002-2003 period, 1,609 mm; 2003-2004 period, $944 \mathrm{~mm}$; 2004-2005 period, $626 \mathrm{~mm})$. The presence of mealybugs in July 2005 was conspicuous throughout the vineyard, and females were easily observed on almost all the plants. Nevertheless, the level of capture in 2005 was lower than expected. The cause of this remains unclear but may be partially explained by three factors: a higher level of parasitism, a larger population of Tyrophagus putrescentiae (Schrank) during the entire season, and a large number of mealybugs, which although adults of reasonable size, did not become sufficiently mature to lay eggs. The mold mite Tyrophagus putrescentiae is a ubiquitous and mainly saprophytic mite (Hughes 1976). It has not been described as a predator of mealybugs but has been reported to be an inconvenience in the mass rearing of the pink pineapple mealybug (Pandey and Johnson 2006). Nevertheless, it has been confirmed as a predator of insects as beetle eggs and larvae (Brust and House 1988, Papadopoulou 2006) and adult mosquitoes (Serpa et al. 2004). In the citrus mealybug reared in our laboratory, these mites caused the total eradication of the mealybug population, and they devoured some mealybugs trapped on the tapes and also mealybug eggs lays in the laboratory.

Analysis of the presence of GLRaV-3 in the mealybugs trapped on the infected plants, revealed a high percentage (almost 75\%) of insects carrying the virus; this level remained stable through the season. Considering the total leafroll infection in plot $\mathrm{F}$, the percentage of virus carrying mealybugs may indicate the level of virus acquisition in field conditions. The infective capacity of these carriers was not determined, but in previous studies the level of transmission was always lower than the level of acquisition when the latter was determined by means of whole individual analysis. Even when the insects carry the virions, they may not be available to be inoculated into a plant (Olmos et al. 2005).

The role played by the citrus mealybug in the transmission of GLRaV-3 remains undefined. The current study revealed an almost total absence of mealybugs in the canopy, the area of contact among plants, and notable differences in levels of infestation among plants. Therefore, movements of mealybugs among plants seem scarce. These data and the low transmission rates obtained in the laboratory assays (Cabaleiro and Segura 1997b, Golino et al. 2002, Krüger et al. 2006, Douglas and Kruger 2008) suggest a very low spread of GLRaV-3 in the field. Nevertheless, the spread was higher than that expected by analysis of the mealybug activity (Cabaleiro and Segura 2006, Cabaleiro et al. 2008). There are three possible explanations for this contradiction: 1) underestimation of the transmission rate in the laboratory assays, 2 ) underestimation of the movement of mealybugs among plants, and 3) existence of an as yet unidentified mechanism of virus transmission. Determination of the transmission rate of mealybug-borne viruses is a very difficult task. The cryptic behavior of the mealybugs and the complexity of the pathosystem make the results of the assays very variable, even when carried out in the same laboratory (Posnette and Strickland 1948, Roivainen 1980, Krüger et al. 2006, Douglas and Kruger 2008). Therefore, important errors may be made in determining the transmission rates, and the actual rates may be much higher.

Taking into the account the present results, the movement of mealybugs among plants seems to be low throughout the canopy due to the low level of infestation, the scarce presence of mealybugs in the green part and the important differences in infestation among plants. This is consistent with the results of Grasswitz and James (2008) obtained for Ps. maritimus, i.e., little movement of mealybugs by walking from plant to plant and preference of mealybugs for concealed locations. Nevertheless specific movements throughout the canopy may take place during possible population explosions. Moreover, other possible means of movement from plant to plant may exist: ants may transport the mealybugs from plant to plant (Rohrbach et al. 1988, Helms and Vinson 2002), the mealybugs may be transported by the wind or agricultural practices such as spraying (Martínez-Ferrer et al. 2003, Sforza et al. 2003, Grasswitz and James 2008), and mealybugs may move along the soil after falling from the canopy alone or with the leaves or with the pruning remains (Bodenheimer 1951). Lo et al. (2006) and Grasswitz \& James (2008) also studied the role played by the wind on the movement of the grape mealybug and remarked on the large numbers of crawlers moved in this way in highly infested vineyards.

The third hypothesis involves an as yet unidentified mechanism of transmission. Several studies of the spread of GLRaV-3 in the field have revealed spread of the disease without the presence of mealybugs or scale insects, which has been attributed to the existence of other mechanism of transmission (Habili et al. 1995, Cabaleiro and Segura 1997a, Habili and Nutter 1997). This may be an insect-mediated mechanism, carried out by an insect, probably a phloem feeder, because the GLRaV-3 is a phloem-restricted virus, or may be a graft-mediated mechanism with transmission linked to the formation of natural root-grafts between plants of different sanitary status (Pethybridge et al. 
2002). The spread of the GLRaV-3 virus in a vineyard and the participation of the citrus mealybug may depend on some or all of the three factors listed above.

In vineyards where the mealybug populations do not reach pest level, measures that can be taken to minimize the transmission of GLRaV-3 mediated by $P$. citri include the use of sticky traps, removal of pruning remains, removal of bark from old plants, and application of water to the trunk during the winter. The sticky traps must be placed on the plants before the movements start to ensure the catch of most mealybugs and also to trap the ants that protect the mealybug population (Tollerup et al. 2004). Adhesive tapes placed around the trunk or sectors of the trunk and impregnated with an appropriate type of glue are suitable traps. The use of sticky traps on the trellis poles is also effective in controlling the activity of the ants. The pruning remains may act as a means of transport for the mealybugs placed on them and facilitate the movement of mealybugs between plants (Bodenheimer 1951). The removal and burning of pruning remains may help to reduce the movement of mealybugs between plants and thus reduce the spread of the GLRaV-3. Bark is an optimum natural shelter for the mealybugs, and its removal allows reduction of the numbers of mealybugs and of the possibility of population explosions occurring. Rain and low winter temperatures seem to play an important role in the winter mortality (Koplow Wies 2004). The application of water, especially on the trunk, may therefore increase the winter mortality and thus reduce the initial population of mealybugs during the season, and consequently the population at the end of the year. These measures are of particular interest when mealybugs are present in high numbers.

\section{Acknowledgments}

We thank Fernando Massó for allowing us to carry the study in his vineyard. We thank Antonia Soto and Aleixandre Beltrà for the mealybug identification. This work was partly funded by a grant from the FEDER and Ministerio de Ciencia y Tecnología (AGL2002-02438).

\section{References Cited}

Bentley, W. J., L. G. Varela, F. G. Zalom, R. J. Smith, A. H. Purcell, P. A. Phillips, D. R. Haviland, K. M. Daane, and M. C. Battany. 2006a. UC IPM pest management guidelines: grape. Vine mealybug. Publication 3448. Agriculture and Natural Resources, University of California.

Bentley, W. J., L. G. Varela, F. G. Zalom, R. J. Smith, A. H. Purcell, P. A. Phillips, D. R. Haviland, K. M. Daane, and M. C. Battany. 2006b. UC IPM pest management guidelines: grape. Mealybugs (Pseudococcus). Publication 3448. Agriculture and Natural Resources. University of California.

Berlinger, M., and A. Gol'berg. 1978. The effect of the fruit sepals on the citrus mealybug population and on its parasite. Entomol. Exp. Appl. 24: 238-243.

Berlinger, M. J. 1977. The Mediterranean vine mealybug and its natural enemies in southern Israel. Pyhytoparasitica 5: 3-14.
Bodenheimer, F. S. 1951. Citrus entomology in the Middle East. W. Junk, The Hague, The Netherlands.

Brust, G. E., and G. J. House. 1988. A study of Tyrophagus putrescentiae (Acari, Acaridae) as a facultative predator of southern corn-rootworm eggs. Exp. Appl. Acarol. 4: 335-344.

Cabaleiro, C., and A. Segura. 1997a. Field transmission of grapevine leafroll associated virus $3(\mathrm{GLRaV}-3)$ by the mealybug Planococcus citri. Plant Dis. 81: 283-287.

Cabaleiro, C., and A. Segura. 1997b. Some characteristics of the transmission of grapevine leafroll associated virus 3 by Planococcus citri Risso. Eur. J. Plant Pathol. 103: 373-378.

Cabaleiro, C., and A. Segura. 2006. Temporal analysis of grapevine leafroll associated virus 3 epidemics. Eur. J. Plant Pathol. 114: 441-446.

Cabaleiro, C., C. Couceiro, S. Pereira, M. Cid, M. Barrasa, and A. Segura. 2008. Spatial analysis of epidemics of Grapevine leafroll associated virus-3. Eur. J. Plant Pathol. 121: 121-130.

Carballeira, A., C. Devesa, R. Retuerto, E. Santillán, and F. Ucieda. 1983. Bioclimatología de Galicia. Fundación Pedro Barrié de La Maza, La Coruña, Spain.

Cid, M., S. Pereira, C. Cabaleiro, F. Faoro, and A. Segura. 2007. Presence of Grapevine leafroll-associated virus 3 in primary salivary glands of the mealybug vector Planococcus citri suggests a circulative transmission mechanism. Eur. J. Plant Pathol. 118: 23-30.

Douglas, N., and K. Kruger. 2008. Transmission efficiency of Grapevine leafroll-associated virus 3 (GLRaV-3) by the mealybugs Planococcus ficus and Pseudococcus longispinus (Hemiptera: Pseudococcidae). Eur. J. Plant Pathol. 122: 207-212.

Geiger, C. A., and K. M. Daane. 2001. Seasonal movement and distribution of the grape mealybug (Homoptera: Pseudococcidae): developing a sampling program for San Joaquin Valley vineyards. J. Econ. Entomol. 94: 291-301.

Golino, D. A., S. T. Sim, R. Gill, and A. Rowhani. 2002. California mealybugs can spread grapevine leafroll disease. Calif. Agric. 56: 196-201.

Grasswitz, T. R., and D. G. James. 2008. Movement of grape mealybug, Pseudococcus maritimus, on and between host plants. Entomol. Exp. Appl. 129: 268-275.

Habili, N., and F. W. Nutter. 1997. Temporal and spatial analysis of grapevine leafroll-associated virus 3 in Pinot Noir grapevines in Australia. Plant Dis. 81: 625-628.

Habili, N., C. F. Fazeli, A. Ewart, R. Hamilton, R. Cirami, P. Saldarelli, A. Minafra, and M. A. Rezaian. 1995. Natural spread and molecular analysis of Grapevine Leafroll-Associated Virus-3 in Australia. Phytopathology 85: 14181422.

Helms, K. R., and S. B. Vinson. 2002. Widespread association of the invasive ant Solenopsis invicta with an invasive mealybug. Ecology 83: 2425-2438.

Hughes, A. M. 1976. The mites of stored food and houses. Ministry of Agriculture, Fisheries and Food, London, United Kingdom.

Instituto Nacional de Meteorología (España). 2001. Guía resumida del clima en España, 1971-2000. Centro de Publicaciones, Madrid, Spain.

Kliewer, W. M. 1967. Annual cyclic changes in the concentration of free amino acids in grapevines. Am. J. Enol. Vitic. 18: 126-137.

Koplow Wies, C. E. 2004. Monitoreo y control fisico de chanchitos blancos (Pseudococcus viburni (Signoret)) en vid. Antecedentes para el manejo integrado, pp. 58. In Facultad de Agronomía e ingeniería Forestal. Pontificia Universidad Catolica de Chile, Santiago de Chile, Chile. 
Krishnamoorthy, A., and S. Singh. 1987. Biological control of citrus mealybug, Planococcus citri with an introduced parasite, Leptomastix dactylopii in India. Biocontrol 32: 143-148.

Krüger, K., D. Saccaggi, and N. Douglas. 2006. Grapevine leafroll-associated virus 3-vector interactions: transmission by the mealybugs Planococcus ficus and Pseudococcus longispinus (Hemiptera: Pseudococcidae), pp. 130-131. In Extended abstracts 15th Meeting ICVG, Stellenbosch, South Africa, 3-7 April 2006. South African Society of Enology and Viticulture, Stellenbosch, South Africa.

Le Rü, B., and Y. Iziquel. 1990. Experimental-study on mechanical effect of rainfall using a rain simulator on cassava mealybug populations, Phenacoccus manihoti. Acta Oecol. 11: 741-754.

Lo, P., V. Bell, J. Walker, L. Cole, D. Rogers, and J. Charles. 2006. Ecology and management of mealybugs in vineyards, 2005-2006. The Horticulture and Food Research Institute of New Zealand. Auckland, New Zealand.

Lucas Espadas, A. 2002. Comportamiento de melazo (Pseudococcus citri Risso) en uva de mesa en la Región de Murcia. Alternativas de control biológico. Phytoma-España 138: $28-36$.

Martelli, G. P., and E. Boudon-Padieu. 2006. Directory of infectious diseases of grapevines and viroses and viruslike diseases of the grapevine: bibliographic report 1998 2004. Le Centre International de Hautes Etudes Agronomiques Méditerranéennes, Bari, Italy.

Martínez-Ferrer, M. T., F. García-Marí, and J. L. Ripolles. 2003. Population dynamics of Planococcus citri Risso (Homoptera: Pseudococcidae) in citrus groves in Spain. IOBC wprs Bull. 26: 149-161.

Meteogalicia. 2009. Estacións meteorolóxicas-Estación de Lourizán. (http://www.meteogalicia.es/galego/observacion/ estacions $/$ estacions.asp?idEst $=10064 \&$ idprov $=3$ ).

Minafra, A., and A. Hadidi. 1994. Sensitive detection of Grapevine virus A, virus B, or leafroll-associated-III from viruliferous mealybugs and infected tissue by $\mathrm{cDna}$ amplification. J. Virol. Methods 47: 175-187.

Morandi, W. J., A. D. Gruetzmacher, M. Botton, and A. Bertin. 2008. Biology and fertility life table of Planococcus citri in different vegetative structures of grape cultivars. Pesqui. Agropec. Bras. 43: 941-947.

Nassar, A. R., and W. M. Kliewer. 1966. Free amino acids in various parts of Vitis vinifera at different stages of development. Am. Soc. Hortic. Sci. 89: 281-294.

Olmos, A., E. Bertolini, M. Gil, and M. Cambra. 2005. Realtime assay for quantitative detection of non-persistently transmitted Plum pox virus RNA targets in single aphids. J. Virol. Methods. 128: 151-155.

Pandey, R. R., and M. W. Johnson. 2006. Enhanced production of pink pineapple mealybug, Dysmicoccus brevipes (Hemiptera: Pseudococcidae). Biocontrol Sci. Technol. 16: $389-401$.
Papadopoulou, S. C. 2006. Tyrophagus putrescentiae (Schrank) (Astigmata: Acaridae) as a new predator of Lasioderma serricorne (F.) (Coleoptera: Anobiidae) in tobacco stores in Greece. J. Stored Prod. Res. 42: 391-394.

Pethybridge, S. J., C. R. Wilson, F. S. Hay, G. W. Leggett, and L. J. Sherriff. 2002. Mechanical transmission of Apple mosaic virus in Australian hop (Humulus lupulus) gardens. Ann. Appl. Biol. 141: 77-85.

Posnette, A. F., and A. H. Strickland. 1948. Virus diseases of cacao in West Africa. 3. Technique of insect transmission. Ann. Appl. Biol. 35: 53-63.

Rohrbach, K. G., J. W. Beardsley, T. L. German, N. J. Reimer, and W. G. Sanford. 1988. Mealybug wilt, mealybugs, and ants on pineapple. Plant Dis. 72: 558-565.

Roivainen, O. 1980. Mealybugs, pp. 15-38. In K. F. Harris and K. Maramorosch [eds.], Vectors of plant pathogens. Academic, New York.

Rosciglione, B., and M. A. Castellano. 1985. Further evidence that mealybugs can transmit grapevine virus A (GVA) to herbaceous host. Phytopathol. Mediterranea 24: 186-188.

Ruiz Castro, A. 1965. Plagas y enfermedades de la vid. Instituto Nacional de Investigaciones Agronomicas, Madrid, Spain.

Serpa, L.L.N., M. R. Franzolin, D. M. Barros-Battesti, and I. Kakitani. 2004. Tyrophagus putrescentiae predando insetos adultos de Aedes aegypti e Aedes albopictus em laboratório. Rev. Saude Publica, Sao Paulo 38: 735-737.

Sforza, R., E. Boudon-Padieu, and C. Greif. 2003. New mealybug species vectoring Grapevine leafroll-associated viruses-1 and -3 (GLRaV-1 and -3). Eur. J. Plant Pathol. 109: 975-981.

Tollerup, K. E., M. K. Rust, K. W. Dorschner, P. A. Phillips, and J. H. Klotz. 2004. Low-toxicity baits control ants in citrus orchards and grape vineyards. Calif. Agric. 58: 213217.

Varela, L., R. Smith, M. Battany, and W. Bentley. 2006. Grape, obscure or vine-which mealybug is it; why should you care? Pract. Winery Vineyard XXVII: 37-46.

Walton, V. M., and K. L. Pringle. 2004a. A survey of mealybugs and associated natural enemies in vineyards in the Western Cape province, South Africa. S. Afr. J. Enol. Vitic. 25: 23-25.

Walton, V. M., and K. L. Pringle. 2004b. Vine mealybug, Planococcus ficus (Signoret) (Hemiptera: Pseudococcidae), a key pest in south African vineyards. A review. S. Afr. J. Enol. Vitic. 25: 54-62.

Walton, V. M., K. M. Daane, and K. L. Pringle. 2004. Monitoring Planococcus ficus in South African vineyards with sex pheromone-baited traps. Crop Prot. 23: 1089-1096.

Received 16 July 2009; accepted 23 December 2009. 